\title{
HUBUNGAN PAPARAN ASAP ROKOK DARI SUAMI PADA WANITA USIA 15-57 TAHUN DENGAN KEJADIAN BAYI BERAT LAHIR RENDAH DI INDONESIA (ANALISIS DATA LANJUTAN IFLS-5 TAHUN 2014)
}

\section{The Association of Husband's Cigarette Smoking Exposure to Low Birth Weight among Mothers Aged 15-57 years in Indonesia (IFLS-5 Data Analysis)}

\author{
Stevy Elisabeth D Simamora ${ }^{1 *}$, Sudarto Ronoatmodjo ${ }^{2}$ \\ ${ }^{1}$ Program Magister Epidemiologi, Fakultas Kesehatan Masyarakat, Universitas Indonesia \\ ${ }^{2}$ Departemen Epidemiologi, Fakultas Kesehatan Masyarakat, Universitas Indonesia \\ Kampus Baru UI Depok, Jawa Barat - 16424 Indonesia \\ E-mail: stevy.elisabethmora@gmail.com
}

Naskah masuk 30 Januari 2020; review 23 Maret 2020; disetujui terbit 26 Juni 2020

\begin{abstract}
Background: The results of Riskesdas (Basic Health Research) showed that the national proportion of low birth weight (LBW) in Indonesia was 10.2 percent in 2013 and 6.2 percent in 2018. Survey conducted by Global Adult Tobacco Survey in 2011 found that 67 percent of men in Indonesia smoke. Meanwhile in 2011-2015, the prevalence of second-hand smoking exposure at home was 78.4 percent and more than half of second-hand smoking are vulnerable groups such as women and under-five children.

Objective: The aim of this study was to examine the association of husband's cigarette smoking exposure to LBW among mothers aged 15-57.

Method: This study used secondary data from $5^{\text {th }}$ Indonesia Family Life Survey (IFLS-5) in 2014 with crosssectional design. The sample of this study was 1.599 women aged 15-57. Multivariate analysis was conducted using cox regression and backward elimination procedure model methods.

Results: This study showed that 73.5 percent of husbands were cigarette smokers and the proportion of LBW was 7.5 percent. The exposure of husband's cigarette smoking didn't increase the risk of LBW after controlling for antenatal care visit variable (PR 1,096; 95\% CI 0.721-1.66).

Conclusion: Despite of statistical insignificance, the proportion of $L B W$ among mothers who exposed with husband's cigarette smoking is slightly higher than mothers with non-smoker's husbands.
\end{abstract}

Keywords: IFLS, low birth weight, second-hand smoking

\begin{abstract}
Abstrak
Latar belakang: Di Indonesia berdasarkan data Riset Kesehatan Dasar (Riskesdas), kejadian bayi berat lahir rendah (BBLR) pada tahun 2013 yaitu 10,2 persen dan pada tahun 2018 sebesar 6,2 persen. Survei yang dilakukan oleh Global Adult Tobacco Survey tahun 2011 diperoleh hasil bahwa 67 persen laki-laki di Indonesia merokok. Sementara itu pada tahun 2011-2015 prevalensi perokok pasif yang terpapar asap rokok di rumah sekitar 78.4 persen, lebih dari separuh perokok pasif adalah kelompok rentan seperti perempuan dan balita.

Tujuan: Untuk mengetahui hubungan paparan asap rokok dari suami pada wanita usia 15-57 tahun dengan kejadian BBLR.

Metode: Penelitian ini menggunakan desain studi cross- sectional dengan data sekunder $5^{\text {th }}$ Indonesia Family Life Survey (IFLS-5) tahun 2014. Sampel adalah 1.599 wanita 15-57 tahun. Analisis data mulitvariat menggunakan cox regression dan metode backward elimination procedures model.

Hasil: Sebanyak 73,5 persen suami adalah perokok aktif dan proporsi bayi dengan berat lahir rendah sebesar 7,5 persen. Paparan asap rokok suami tidak meningkatkan risiko kejadian BBLR setelah dikontrol variabel kunjungan pemeriksaan kehamilan (PR 1,096; 95\% CI 0,721-1,66).

Kesimpulan: Proporsi kejadian BBLR pada ibu yang mempunyai suami perokok aktif sedikit lebih tinggi dari pada ibu yang mempunyai suami tidak merokok, meskipun menunjukkan perbedaan yang tidak bermakna.
\end{abstract}

Kata kunci: IFLS, BBLR, merokok pasif 


\section{PENDAHULUAN}

Secara global sebanyak 2,6 juta bayi yang baru lahir meninggal pada tahun 2016 atau 7.000 kematian bayi baru lahir setiap hari. Kematian neonatal menyumbang 46 persen dari seluruh kematian balita, angka ini meningkat dari tahun 2000 yaitu sekitar 41 persen. ${ }^{1}$ Faktor penyebab kematian bayi sangat beragam, salah satunya adalah karena berat lahir rendah. Badan Kesehatan Dunia (WHO) mendefinisikan bayi berat lahir rendah (BBLR) adalah bayi dengan berat lahir kurang dari 2.500 gram. BBLR merupakan indikator yang dikaitkan dengan peningkatan morbiditas dan mortalitas pada neonatus. Angka kematian bayi (AKB) di Indonesia sampai dengan saat ini masih tergolong tinggi dibandingkan dengan berbagai negara Association of Southeast Asia Nations (ASEAN).

Berdasarkan data yang diterbitkan oleh WHO pada tahun 2014, BBLR berkontribusi sekitar 60-80 persen sebagai penyebab kematian neonatal. Prevalensi BBLR secara global adalah 15,5-20 persen, yang berarti sekitar 20 juta bayi lahir dengan berat badan rendah setiap tahun dan sebagian besar $(96,5 \%)$ terjadi di negara berkembang. Prevalensi berat lahir rendah di seluruh wilayah di dunia bervariasi - sebagian besar kelahiran dengan berat lahir rendah terjadi di negara-negara berpenghasilan rendah dan menengah, terutama di populasi yang paling rentan. Bayi berat lahir rendah paling tinggi yaitu mencakup 28 persen di Asia selatan, 13 persen di Sub-Sahara Afrika dan 9 persen di Amerika Latin. Negara di kawasan Asia seperti Bangladesh memiliki prevalensi BBLR sekitar 22 persen sedangkan untuk negara di kawasan Asia Tenggara seperti Thailand dan Singapura memiliki prevalensi BBLR berturut-turut sekitar 8 persen dan 9 persen. $^{2}$

Banyak faktor yang berkontribusi terhadap kejadian BBLR. Menurut Ohlsson dan Shah dalam buku Determinants and Prevention of

\footnotetext{
*Korespondensi: stevy.elisabethmora@gmail.com

(C) Badan Penelitian dan Pengembangan Kesehatan ISSN: 2354-8762 (elektronik); ISSN: 2087-703X (cetak)
}

Low Birth Weight: A Synopsis of the Evidence dimana mereka mengumpulkan dan mengkaji semua penelitian mengenai determinan terjadinya BBLR di antaranya adalah faktor demografi ibu (usia ibu, paritas, jarak kehamilan, status perkawinan, dan jumlah kehamilan), riwayat aborsi, dan gaya hidup (merokok, alkohol, kafein, penggunaan narkoba, penggunaan obat-obatan herbal, dan olahraga), pelayanan kesehatan (pemeriksaan kehamilan dan deteksi dini janin), lingkungan (polusi udara dan air, penggunaan pestisida, musim yang bervariasi), pekerjaan, kebisingan, kekerasan, dan trauma ibu. Selain itu, terdapat faktor gizi, termasuk asupan protein, zat besi, folat asam, seng, kalsium, minyak ikan, dan beberapa mikronutrien dan faktor infeksi, termasuk infeksi saluran kemih, vaginosis bakteri, klamidia, sifilis, trikomoniasis, gonore, dan malaria selama masa kehamilan. Salah satu faktor penting di antara multifaktor tersebut adalah paparan pralahir terhadap rokok yang berasal dari pasangan atau lingkungan pada ibu hamil (perokok pasif) yang memberikan efek yang kurang baik bagi ibu maupun janinnya. ${ }^{3}$

Menurut WHO, paparan terhadap asap rokok pada kehamilan juga dikaitkan dengan risiko sekitar 22 persen bayi akan lahir dengan berat lahir rendah $(<2500 \quad \mathrm{~g}) .{ }^{4} \quad$ Seperti yang dilaporkan oleh The Tobacco Atlas dan Global Adult Tobacco Survey (GATS) di Indonesia, prevalensi laki-laki yang merokok sekitar 67 persen dan prevalensi perokok pasif yang terpapar asap rokok di rumah sekitar 78,4 persen, ${ }^{5}$ sementara itu prevalensi BBLR di Indonesia berdasarkan hasil Riskesdas 2013 sekitar 10,2 persen. ${ }^{5}$

Hasil penelitian lain dari BMA Tobacco Control Resource Centre melaporkan bahwa asap rokok selama kehamilan berisiko melahirkan BBLR sekitar 1,5-9,9 kali dibandingkan dengan ibu hamil yang tidak terpapar asap rokok. ${ }^{6}$ 
Paparan asap rokok terhadap kelompok rentan seperti ibu hamil dan bayi merupakan masalah yang cukup sulit dihindari di negara berkembang seperti Indonesia. Tidak hanya berdampak bagi kesehatan para perokok tetapi juga bagi orang yang menghirup asap rokok (perokok pasif), seperti gangguan kehamilan, BBLR, sampai dengan kematian bayi. Saat ibu hamil merokok ataupun sebagai perokok pasif yang terpapar asap rokok dari suaminya, bahan kimia yang terkandung dalam rokok akan masuk ke janin melalui plasenta. ${ }^{7}$ Paparan asap tembakau mempengaruhi semua tahap reproduksi manusia. Nikotin merupakan zat kimia yang terpenting dalam komponen tembakau. Pada plasenta ibu yang merokok ditemukan sekitar 15 persen konsentrasi nikotin lebih tinggi dalam darah ibu. Karbon monoksida dalam asap dapat mempengaruhi pertumbuhan dan kemampuan bayi, menyebabkan berat lahir rendah. Ibu yang merokok dikaitkan dengan peningkatan risiko kehamilan ektopik, ketuban pecah dini, abruptio plasenta, plasenta previa, keguguran, kelahiran mati, kelahiran prematur, berat lahir rendah, usia gestasi yang kecil, dan anomali kongenital seperti bibir sumbing. Setelah lahir, risiko sindrom kematian bayi mendadak (SIDS) meningkat di antara keturunan wanita yang merokok selama atau setelah kehamilan. ${ }^{8}$

Penelitian di Indonesia menunjukkan hasil bahwa semua ibu yang terpapar asap rokok dari suami perokok berat melahirkan bayi dengan berat lahir rendah. ${ }^{9}$ Penelitian yang dilakukan oleh Lestari K dkk dengan menggunakan desain kasus kontrol di Kabupaten Gianyar membuktikan bahwa paparan asap rokok suami dan paparan asap rokok anggota keluarga meningkatkan risiko kejadian BBLR masingmasing dengan OR 7,479 (95\% CI 2,05827,175) dan 9,002 (95\% CI 2,434-33,286). Berbeda dengan penelitian yang dilakukan Riska Rasydin menggunakan data Riskesdas 2013 dengan analisis cox regression, mengungkapkan bahwa proporsi BBLR lebih banyak terjadi pada ibu yang merokok pasif yaitu 5,3 persen, sementara risiko ibu perokok pasif sekitar 1,2 kali untuk melahirkan bayi BBLR dibandingkan dengan ibu yang bukan perokok pasif setelah dikontrol oleh status ekonomi dan paritas, meskipun secara statistik tidak bermakna. ${ }^{10}$

Penelitian ini bertujuan untuk mengetahui hubungan paparan asap rokok dari suami terhadap kejadian BBLR yang dikontrol oleh variabel kovariat yang terdiri dari variabel pendidikan, tempat tinggal, pekerjaan, usia ibu melahirkan, konsumsi tablet zat besi, usia gestasi, jenis kelamin bayi, kelahiran kembar, kunjungan antenatal care (ANC), dan komplikasi kehamilan dengan menggunakan data Indonesia Family Life Survey (IFLS) 5 tahun 2014.

\section{METODE}

Penelitian ini menggunakan data sekunder dari Indonesia Family Life Survey (IFLS) atau Survei Aspek Kehidupan Rumah Tangga Indonesia (Sakerti) tahun 2014 dengan desain studi cross-sectional. IFLS adalah survei berkelanjutan dari kerja sama lembaga penelitian dari Amerika Serikat RAND dan SurveyMeter. Data IFLS di Indonesia mulai dikumpulkan pada tahun 1993 (IFLS-1) sampai dengan tahun 2014 (IFLS-5). IFLS-5 tahun 2014 dilakukan di 13 provinsi di Indonesia yaitu Provinsi Sumatera Utara, Sumatera Barat, Riau, Jambi, Kepulauan Riau, Bangka Belitung, Sumatera Selatan, Lampung, seluruh provinsi di Jawa, Bali, Nusa Tenggara Barat, Kalimantan, Sulawesi Selatan dan Sulawesi Barat. Data IFLS yang digunakan pada penelitian ini adalah data IFLS-5 versi 1.3 yang dirilis pada 12 April 2017.

Data diperoleh dengan cara mendaftar akun resmi di situs Research and Development Corporation (RAND) melalui alamat https://www.rand.org. Setelah mendaftar maka akan mendapatkan balasan email verifikasi bahwa data IFLS sudah bisa diakses dan data yang dibutuhkan untuk penelitian dapat diunduh. IFLS-5 2014 adalah data dengan jenis data "public domain" yang dapat diakses gratis oleh siapapun. Semua data yang dikumpulkan dan dianalisis dalam penelitian ini hanya digunakan untuk keperluan ilmiah. Identifikasi responden pada IFLS-5 ini sangat dijaga dan hanya dikenal dengan nomor kode IDE subjek saja. Hasil penelitian kemudian akan di-submit dalam bentuk karya publikasi ke situs RAND. Penelitian ini tidak ada perlakuan atau intervensi terhadap sampel penelitian dan telah lulus kaji etik dari Komite Etik Penelitian Fakultas Kesehatan Masyarakat Universitas Indonesia dengan Nomor: 418/UN2.F10/PPM.00.02.2018 tanggal 14 Mei 2018. 
Untuk keperluan analisis dalam penelitian ini, digunakan beberapa buku untuk mengetahui informasi variabel penelitian, yakni buku 4 untuk catatan perkawinan dan catatan kehamilan, buku 3A untuk catatan pendidikan dan status pekerjaan ibu, buku $\mathrm{K}$ untuk lokasi tempat tinggal, buku 3B untuk catatan kebiasaan merokok dari suami. Data mengenai berat lahir pada IFLS-5 ini diperoleh dari data KMS. Setelah mengetahui pertanyaan dari masing-masing buku terkait variabel penelitian, selanjutnya memastikan data tersebut berada di dalam file. Dataset IFLS masih terbagi dalam masing-masing file sesuai dengan topik modul/buku. Peneliti harus menggabungkan masing-masing file data sesuai kebutuhan penelitian. Pada tahap awal peneliti menentukan file data sebagai acuan adalah data yang berisikan informasi riwayat kehamilan pada wanita usia 15-57 tahun (panduan pada buku 4), kemudian digabungkan dengan data merokok (panduan pada buku 3B) untuk mengetahui status merokok suami. Peneliti harus memastikan bahwa data yang digabungkan tersebut merupakan responden pasangan suami dan istri melalui kode rumah tangga.

Variabel pada penelitian ini adalah paparan asap rokok dari suami, BBLR, pendidikan ibu, tempat tinggal, pekerjaan ibu, usia ibu melahirkan, konsumsi tablet zat besi, usia gestasi, jenis kelamin bayi, status kembar, kunjungan ANC, dan komplikasi kehamilan. Paparan asap rokok dari suami berasal dari pertanyaan kebiasaan merokok suami responden yang dikategorikan menjadi "Ya" untuk suami yang merokok dan "Tidak" untuk suami yang tidak merokok. BBLR dikategorikan menjadi "BBLR" jika berat badan lahir anak $<2.500$ gram dan "Tidak BBLR" jika berat badan lahir anak $\geq 2.500$ gram. Pendidikan ibu dikategorikan menjadi "Pendidikan tinggi" dan "Pendidikan rendah". Tempat tinggal dikategorikan menjadi "Perdesaan" dan "Perkotaan". Pekerjaan ibu dikategorikan menjadi "Bekerja" dan "Tidak bekerja". Usia ibu melahirkan dikategorikan menjadi "Risiko rendah" jika usia melahirkan sekitar 20-35 tahun dan "Risiko tinggi" jika usia melahirkan sekitar $<20$ tahun dan >35 tahun. Konsumsi tablet zat besi dikategorikan menjadi "Ya" jika meminum tablet zat besi $>90$ tablet dan "Tidak" jika tidak minum dan $<90$ tablet zat besi. Usia gestasi dikategorikan menjadi "Tidak prematur" jika usia kehamilan antara 37-42 minggu dan "Prematur" jika usia kehamilan <37 minggu atau $>42$ minggu, dan jenis kelamin bayi dikategorikan menjadi "Perempuan" dan "Laki-laki". Status kelahiran kembar dikategorikan menjadi "Ya" jika ibu melahirkan anak kembar dan "Tidak" jika ibu melahirkan anak tunggal.

Riwayat ANC dikategorikan menjadi "Lengkap" jika kunjungan antenatal care ibu melakukan kunjungan ANC >4 kali dan waktu kunjungan sesuai dengan ketentuan Program KIA dan WHO yaitu minimal satu kali kunjungan ANC pada trimester 1 dan trimester 2, serta dua kali pada trimester 2, "Tidak lengkap" jika ibu tidak melakukan kunjungan ANC atau ANC <4 kali. Komplikasi kehamilan dikategorikan "Ada komplikasi" jika ada satu atau lebih keluhan yang dialami oleh ibu pada saat kehamilan berupa: keluar pembengkakan kaki, kesulitan melihat pada siang hari, kesulitan melihat pada malam hari, perdarahan, demam, kejang-kejang atau pingsan, kesakitan karena mau melahirkan sebelum sembilan bulan; dan "Tidak ada" jika ibu tidak pernah mengalami salah satu dari tanda komplikasi selama kehamilan tersebut.

Hipotesis dalam penelitian ini adalah paparan asap rokok suami dari wanita usia 15-57 tahun berhubungan dengan kejadian BBLR. Populasi pada penelitian ini adalah seluruh wanita di Indonesia yang menjadi responden IFLS-5. Cleaning kemudian dilakukan terhadap responden pasangan suami-istri dimana anak terakhir lahir pada periode 2007-2015, yaitu sebanyak 2.720 orang. Data missing selanjutnya dikeluarkan pada variabel status BBLR sebanyak 825 orang, status merokok suami sebesar 214 orang, status merokok ibu sebanyak 43 orang, dan variabel lainnya sebanyak 43 orang. Dengan demikian, eligible population yang diperoleh menjadi total sampel sebanyak 1.599 orang karena telah memenuhi syarat kriteria inklusi dan ekslusi untuk dianalisis. Adapun kriteria inklusi terdiri atas wanita usia 15-57 tahun dengan kelahiran anak terakhir yang lahir hidup dalam kurun waktu 20072015, pernah melahirkan, dan berstatus menikah. Kriteria eksklusi terdiri atas data tentang variabel riwayat merokok suami yang tidak lengkap - data ini diambil dari kuesioner buku 3B dengan pertanyaan "Suami yang mempunyai kebiasaan menghisap rokok/cerutu 
baik pada masa sekarang maupun pada masa lampau (IFLS-5 tahun 2014) dan kebiasaan tersebut masih berlangsung sampai dengan dilakukannya wawancara"; data tidak lengkap mengenai variabel yang diteliti; dan ibu merupakan perokok aktif.

Analisis data dilakukan dengan menggunakan software STATA versi 12 milik laboratorium komputer Fakultas Kesehatan Masyarakat Universitas Indonesia. Analisis dilakukan secara bertahap yaitu analisis univariat untuk mengetahui gambaran atau distribusi data untuk setiap variabel yang diteliti, baik variabel independen maupun dependen; serta analisis bivariat dengan melakukan uji chi-square, besarnya hubungan antara variabel independen dan dependen dinilai dengan menggunakan prevalence ratio $(\mathrm{PR})$ dan $95 \%$ confidence interval (CI). Analisis stratifikasi pada penelitian ini bertujuan untuk melihat adanya potensi dari efek modifikasi atau interaksi dan pengaruh potensi confounding pada masingmasing strata. Penilaian variabel dengan potensi interaksi dengan melihat hasil $p$-value dari hasil Test Homogenity dengan Breslow Day Test dimana $p$-value $<0,05$ ada potensi interaksi. Uji statistik yang akan digunakan adalah cox regression dengan tingkat kepercayaan atau confidence level 95 persen. Analisis multivariat menggunakan metode backward elimination procedures model dengan tahap mengeluarkan satu per satu variabel kovariat dari variabel dengan $p$-value tertinggi dan dinilai perubahan $P R$ dengan membandingkan perubahan nilai $P R$ variabel independen pada full model dan pada reduce model. Confounding dikeluarkan dari model jika $\triangle \mathrm{PR}<10 \%$.

\section{HASIL}

Analisis data dilakukan terhadap 1.599 wanita usia 15-57 tahun yang eligible. Pada penelitian ini kejadian BBLR adalah sebanyak 120 anak $(7,50 \%)$ dan proporsi suami perokok aktif adalah 73,55 persen (Tabel 1). Subjek penelitian yang tinggal di daerah perdesaan sebesar 38,96 persen, dan wanita yang melahirkan pada usia yang berisiko sebesar 18,39 persen. Sebesar 48,28 persen wanita melahirkan bayi dengan jenis kelamin perempuan dan 3,25 persen wanita melahirkan bayi kembar. Sebesar 33,27 persen merupakan wanita bekerja dan 47,59 persen berpendidikan rendah.

Tabel 1. Distribusi frekuensi variabel dependen, independen dan kovariat

\begin{tabular}{|c|c|c|}
\hline & $\begin{array}{c}\mathbf{n} \\
(\mathbf{1 . 5 9 9})\end{array}$ & $\%$ \\
\hline \multicolumn{3}{|l|}{ BBLR } \\
\hline Ya & 120 & 7,50 \\
\hline Tidak & 1.479 & 92,5 \\
\hline \multicolumn{3}{|c|}{ Suami perokok aktif } \\
\hline Ya & 1.176 & 73,55 \\
\hline Tidak & 423 & 26,45 \\
\hline \multicolumn{3}{|c|}{ Daerah tempat tinggal } \\
\hline Perdesaan & 623 & 38,96 \\
\hline Perkotaan & 976 & 61,04 \\
\hline \multicolumn{3}{|l|}{ Usia melahirkan } \\
\hline Berisiko & 294 & 18,39 \\
\hline Tidak berisiko & 1.305 & 81,61 \\
\hline \multicolumn{3}{|l|}{ Jenis kelamin bayi } \\
\hline Perempuan & 772 & 48,28 \\
\hline Laki-laki & 827 & 51,72 \\
\hline \multicolumn{3}{|l|}{ Status kembar } \\
\hline $\mathrm{Ya}$ & 52 & 3,25 \\
\hline Tidak & 1.547 & 96,75 \\
\hline \multicolumn{3}{|l|}{ Pekerjaan ibu } \\
\hline Bekerja & 532 & 33,27 \\
\hline Tidak bekerja & 1.067 & 66,73 \\
\hline
\end{tabular}


(Lanjutan Tabel 1.)

\begin{tabular}{|c|c|c|}
\hline Variabel & $\begin{array}{c}\mathbf{n} \\
(\mathbf{1 . 5 9 9})\end{array}$ & $\%$ \\
\hline \multicolumn{3}{|l|}{ Pendidikan ibu } \\
\hline Rendah & 761 & 47,59 \\
\hline Tinggi & 838 & 52,41 \\
\hline \multicolumn{3}{|l|}{ Usia gestasi } \\
\hline Prematur & 406 & 25,39 \\
\hline Tidak prematur & 1.193 & 74,61 \\
\hline \multicolumn{3}{|l|}{ Riwayat komplikasi } \\
\hline $\mathrm{Ya}$ & 344 & 21,51 \\
\hline Tidak & 1.255 & 78,49 \\
\hline \multicolumn{3}{|l|}{ Konsumsi tablet zat besi } \\
\hline Tidak & 1.018 & 63,66 \\
\hline $\mathrm{Ya}$ & 581 & 36,34 \\
\hline \multicolumn{3}{|l|}{ Riwayat ANC } \\
\hline Tidak lengkap & 200 & 12,51 \\
\hline Lengkap & 1.399 & 87,49 \\
\hline
\end{tabular}

Berdasarkan varibel usia gestasi, wanita yang melahirkan bayi prematur sebesar 25,39 persen, dan wanita dengan riwayat komplikasi sekitar 21,51 persen. Wanita yang mengkonsumsi tablet zat besi minimal 90 tablet selama kehamilan sekitar 36,34 persen, dan wanita dengan riwayat ANC lengkap sekitar 87,49 persen.

Hasil penelitian ini menunjukkan bahwa tidak terdapat hubungan yang signifikan antara paparan asap rokok dari suami terhadap kejadian BBLR ( $p$-value > 0,05). Adapun PR sekitar 1,128 kali (95\% CI 0,754-1,688), artinya paparan asap rokok dari suami (ibu yang mempunyai suami perokok aktif) berisiko 1,128 kali melahirkan BBLR dibanding ibu yang tidak terpapar asap rokok dari suami.

Hasil analisis uji statistik (Tabel 2) menunjukkan bahwa daerah tempat tinggal, pendidikan ibu, usia gestasi, riwayat komplikasi, dan riwayat ANC berhubungan secara signifikan secara statistik terhadap BBLR ( $p$-value $<0,05$ ). Sedangkan variabel usia melahirkan, jenis kelamin bayi, kelahiran kembar, pekerjaan ibu dan komsumsi tablet zat besi secara statistik tidak signifikan terhadap kejadian BBLR ( $p$-value > 0,05) dan akan dievaluasi kembali dengan analisis stratifikasi untuk diikutsertakan dalam analisis selanjutnya.

Tabel 2 Analisis hubungan paparan asap rokok suami dari wanita usia 15-57 tahun dan variabel kovariat dengan kejadian BBLR di Indonesia tahun 2014

\begin{tabular}{|c|c|c|c|c|c|c|c|c|}
\hline \multirow[b]{3}{*}{ Variabel } & \multicolumn{4}{|c|}{ Kategori BBLR } & \multirow[b]{3}{*}{ Total } & \multirow{3}{*}{$\begin{array}{c}\text { P- } \\
\text { value }\end{array}$} & \multirow[b]{3}{*}{ PR } & \multirow[b]{3}{*}{$95 \% \mathrm{CI}$} \\
\hline & \multicolumn{2}{|c|}{ BBLR } & \multicolumn{2}{|c|}{ Tidak BBLR } & & & & \\
\hline & $\mathbf{n}$ & $\%$ & $\mathbf{n}$ & $\%$ & & & & \\
\hline \multicolumn{9}{|l|}{$\begin{array}{l}\text { Suami perokok } \\
\text { aktif }\end{array}$} \\
\hline $\mathrm{Ya}$ & 91 & 7,74 & 1.085 & 92,26 & 1.176 & 0,554 & 1,128 & $0,754-1,688$ \\
\hline Tidak & 29 & 6,86 & 394 & 93,14 & 423 & & & \\
\hline \multicolumn{9}{|l|}{$\begin{array}{l}\text { Daerah tempat } \\
\text { tinggal }\end{array}$} \\
\hline Perdesaan & 61 & 9,79 & 562 & 90,21 & 623 & $0,005^{*}$ & 1,619 & $1,148-2,283$ \\
\hline Perkotaan & 59 & 6,05 & 917 & 93,95 & 976 & & & \\
\hline \multicolumn{9}{|l|}{ Usia melahirkan } \\
\hline Berisiko tinggi & 25 & 8,50 & 269 & 91,50 & 294 & 0,471 & 1,168 & $0,765-1,781$ \\
\hline Tidak berisiko & 95 & 7,28 & 1.210 & 92,72 & 1.305 & & & \\
\hline \multicolumn{9}{|l|}{ Jenis kelamin bayi } \\
\hline Perempuan & 63 & 8,16 & 709 & 91,84 & 772 & 0,336 & 1,184 & $0,838-1,671$ \\
\hline
\end{tabular}




\begin{tabular}{|c|c|c|c|c|c|c|c|c|}
\hline \multirow[b]{5}{*}{ Variabel } & 57 & 6,89 & 770 & 93,11 & 827 & & & \\
\hline & & & & & & & \multicolumn{2}{|c|}{ (Lanjutan Tabel 2.) } \\
\hline & \multicolumn{4}{|c|}{ Kategori BBLR } & \multirow[b]{3}{*}{ Total } & \multirow{3}{*}{$\begin{array}{c}\text { P- } \\
\text { value }\end{array}$} & \multirow[b]{3}{*}{ PR } & \multirow[b]{3}{*}{$95 \% \mathrm{CI}$} \\
\hline & \multicolumn{2}{|c|}{ BBLR } & \multicolumn{2}{|c|}{ Tidak BBLR } & & & & \\
\hline & $\mathbf{n}$ & $\%$ & $\mathbf{n}$ & $\%$ & & & & \\
\hline \multicolumn{9}{|l|}{ Status kembar } \\
\hline $\mathrm{Ya}$ & 5 & 9,62 & 47 & 90,38 & 52 & 0,557 & 1,293 & $0,551-3,031$ \\
\hline Tidak & 115 & 7,43 & 1.432 & 92,57 & 1.547 & & & \\
\hline \multicolumn{9}{|l|}{ Pekerjaan ibu } \\
\hline Bekerja & 33 & 6,2 & 499 & 93,8 & 532 & 0,163 & 0,76 & $0,516-1,120$ \\
\hline Tidak bekerja & 87 & 8,15 & 980 & 91,85 & 1.067 & & & \\
\hline \multicolumn{9}{|l|}{ Pendidikan ibu } \\
\hline Rendah & 73 & 9,59 & 688 & 90,41 & 761 & $0,002 *$ & 1,710 & $1,201-2,434$ \\
\hline Tinggi & 47 & 5,61 & 791 & 94,39 & 838 & & & \\
\hline \multicolumn{9}{|l|}{ Usia gestasi } \\
\hline Prematur & 99 & 8,30 & 1.094 & 91,70 & 1.193 & $0,038^{*}$ & 1,604 & $1,015-2,534$ \\
\hline Tidak prematur & 21 & 5,17 & 385 & 94,83 & 406 & & & \\
\hline \multicolumn{9}{|l|}{ Riwayat } \\
\hline \multicolumn{9}{|l|}{ komplikasi } \\
\hline $\mathrm{Ya}$ & 35 & 10,17 & 309 & 89,83 & 344 & $0,033 *$ & 1,502 & $1,032-2,186$ \\
\hline Tidak & 85 & 6,77 & 1.170 & 93,23 & 1.255 & & & \\
\hline \multicolumn{9}{|l|}{$\begin{array}{l}\text { Konsumsi tablet } \\
\text { zat besi }\end{array}$} \\
\hline Tidak & 84 & 8,25 & 934 & 91,75 & 1.018 & 0,133 & 1,331 & $0,913-1,941$ \\
\hline $\mathrm{Ya}$ & 36 & 6,20 & 545 & 93.80 & 581 & & & \\
\hline \multicolumn{9}{|l|}{ Riwayat ANC } \\
\hline Tidak lengkap & 26 & 13 & 174 & 87 & 200 & $0,001 *$ & 1,934 & $1,286-2,910$ \\
\hline Lengkap & 94 & 6,72 & 1.305 & 93,28 & 1.399 & & & \\
\hline
\end{tabular}

*P-value <0,05; PR: Prevalence ratio

Berdasarkan hasil analisis stratifikasi dengan uji Test Homogenity pada semua variabel kovariat tidak ada interaksi (nilai $p>0,05$ ) dan tidak terdapat confounding (perbedaan $\mathrm{PR}_{\text {Crude }}$ dan $\mathrm{PR}_{\mathrm{MH}}$ dengan $\Delta \mathrm{PR}>10 \%$ ) pada hubungan suami merokok aktif dengan BBLR pada wanita usia 15-57 tahun di Indonesia tahun 2014.

Tabel 3. Seleksi kandidat model multivariat

\begin{tabular}{lcccc}
\hline \multicolumn{1}{c}{ Variabel } & $p$-value & PR & $95 \%$ CI & Keterangan \\
\hline Suami perokok aktif & 0,554 & 1,128 & $0,754-1,688$ & Variabel utama \\
Daerah tempat tinggal & 0,005 & 1,619 & $1,148-2,283$ & Kandidat \\
Usia melahirkan & 0,471 & 1,168 & $0,765-1,781$ & Kandidat \\
Jenis kelamin bayi & 0,336 & 1,184 & $0,838-1,671$ & Kandidat \\
Status kembar & 0,558 & 1,293 & $0,551-3,031$ & Kandidat \\
Pekerjaan ibu & 0,163 & 0,76 & $0,516-1,120$ & Kandidat \\
Pendidikan ibu & 0,002 & 1,71 & $1,201-2,434$ & Kandidat \\
Usia gestasi & 0,038 & 1,604 & $1,015-2,534$ & Kandidat \\
Riwayat komplikasi & 0,033 & 1,502 & $1,032-2,186$ & Kandidat \\
Konsumsi tablet zat besi & 0,133 & 1,331 & $0,913-1,941$ & Kandidat \\
Riwayat ANC & 0,001 & 1,934 & $1,286-2,910$ & Kandidat \\
\hline
\end{tabular}

PR: Prevalence ratio; SE: Standard error 
Pada Tabel 3 didapatkan hasil seleksi bivariat dengan variabel daerah tempat tinggal, pekerjaan ibu, pendidikan ibu, usia gestasi, riwayat komplikasi, konsumsi tablet zat besi, dan riwayat ANC memiliki $p$-value $<0,25$ dan akan masuk ke dalam model analisis multivariat. Berdasarkan substansi variabel usia melahirkan, jenis kelamin bayi, dan status kembar mempunyai pengaruh yang penting dengan kejadian BBLR maka variabel tersebut akan dimasukan ke dalam analisis multivariat meskipun $p$-value $>0,25$.

Analisis multivariat menggunakan metode backward elimination procedures model dengan tahap mengeluarkan satu per satu variabel kovariat dari variabel dengan $p$-value tertinggi dan dinilai perubahan PR-nya dengan membandingkan perubahan nilai $\mathrm{PR}$ variabel independen pada full model dan pada reduce model. Proses pengujian confounding dari full model dengan mengeluarkan satu per satu variabel wilayah, usia melahirkan, jenis kelamin bayi, status kembar, pekerjaan ibu, pendidikan ibu, usia gestasi, riwayat komplikasi, konsumsi tablet zat besi, dan riwayat ANC. Penilaian confounding merupakan tahap akhir dari analisis multivariat dan variabel yang masuk dalam model akhir analisis multivariat adalah suami perokok aktif. Pada pengujian confounding diperoleh hasil bahwa variabel riwayat ANC merupakan confounding.

Tabel 4. Model akhir analisis multivariat hubungan paparan asap rokok suami dengan kejadian BBLR pada wanita usia 15-57 tahun di Indonesia tahun 2014

\begin{tabular}{lrrrl}
\hline \multicolumn{1}{c}{ Variabel } & Koefisien & \multicolumn{1}{l}{ PR } & \multicolumn{1}{c}{ SE } & \multicolumn{1}{c}{$p$-value (95\% CI) } \\
\hline Suami perokok aktif & 0,091 & 1,096 & 0,234 & $0,667(0,721-1,66)$ \\
Riwayat ANC & 0,654 & 1,924 & 0,427 & $0,003(1,245-2,972)$ \\
\hline
\end{tabular}

PR: Prevalence ratio; SE: Standard error

Model akhir dengan analisis multivariat pada Tabel 4 menunjukkan bahwa wanita usia 15-57 tahun yang terpapar asap rokok dari suami memiliki peluang sekitar 1,096 kali (CI 95\% 0,721-1,66) mengalami BBLR bila dibandingkan ibu yang tidak terpapar asap rokok dari suami setelah dikontrol riwayat kunjungan ANC.

\section{PEMBAHASAN}

Pada penelitian ini, diketahui proporsi BBLR pada ibu yang mempunyai suami perokok aktif sekitar 7,5 persen. Hasil ini cukup tinggi dibandingkan dengan hasil penelitian mengenai hubungan merokok pasif dengan BBLR menggunakan data Riskesdas 2013 dimana diperoleh hasil proporsi BBLR sekitar 4,99 persen. ${ }^{10}$ Berdasarkan data Riskesdas 2007, 2010, 2013, dan 2018 diketahui bahwa prevalensi BBLR di Indonesia sudah cenderung mengalami penurunan sejak tahun 2007 yaitu sekitar 11,5 persen, 10,2 persen pada tahun 2013 dan 6,2 persen pada tahun 2018. Namun penurunan prevalensi BBLR harus lebih diperhatikan karena berdasarkan data Riskesdas, persentase anak balita yang memiliki catatan berat badan lahir sekitar 56,6 persen. ${ }^{11-13}$ Hal ini artinya sebagian besar data berat lahir tidak dicatat atau disalin pada dokumen/catatan yang dimiliki oleh anggota rumah tangga, seperti buku KIA, KMS, atau buku catatan kesehatan anak lainnya. Kondisi ini akan mempengaruhi hasil yang sesungguhnya mengenai besaran masalah BBLR. ${ }^{14}$ Buku KIA merupakan bentuk peran serta aktif keluarga dan masyarakat dalam bidang kesehatan ibu dan anak, dan keberhasilan penerapan buku KIA sebagai salah satu alat untuk meningkatkan cakupan pelayanan KIA tidak terlepas dari peran para pihak terkait dengan kesehatan ibu hamil, ibu bersalin, bayi baru lahir, bayi dan anak balita.

Proporsi ibu yang mempunyai suami perokok aktif adalah 73,5 persen. Hasil ini hampir sama dengan hasil survei GATS di Indonesia dimana pada tahun 2011-2015 prevalensi perokok pasif yang terpapar asap rokok di rumah sekitar 78,4 persen. ${ }^{5}$ Selain itu lebih dari separuh perokok pasif adalah kelompok rentan seperti 
perempuan dan balita. ${ }^{8}$ Berdasarkan data SDKI 2012 diperoleh hasil bahwa sekitar 72 persen pria kawin adalah perokok aktif. Sekitar 64 persen rumah tangga terpapar setiap hari menjadi perokok pasif. Rumah tangga perdesaan (68\%) lebih besar terpapar menjadi perokok pasif dibanding rumah tangga perkotaan $(60 \%) .{ }^{15}$ Sedangkan data Riskesdas 2013 menunjukkan bahwa proporsi perokok laki-laki usia $>15$ tahun sekitar 64,9 persen. ${ }^{12}$

Hasil penelitian ini menyatakan bahwa pengaruh asap rokok dari suami pada ibu usia 15-57 tahun tidak berhubungan dengan kejadian BBLR di Indonesia setelah dikontrol variabel riwayat ANC dengan PR sebesar 1,096 (CI 95\% 0,721-1,66). Penelitian lainnya yang dilakukan oleh Goel et al. di India dengan desain studi cross-sectional diperoleh hasil yang sama, kejadian BBLR lebih banyak pada kelompok yang terpajan pada ETS dibandingkan dengan kelompok tidak terpajan $(32,6 \%$ vs $25,3 \%)$, perbedaannya tidak signifikan, OR crude sebesar 1,43 (95\% CI 0,95-2,16) dan OR adjusted 1,03 (95\%CI: 0,651,65). ${ }^{16}$ Penelitian yang dilakukan oleh Rasyidin menggunakan data Riskesdas 2013 menemukan hal yang sama bahwa merokok pasif pada ibu usia 15-54 tahun mempunyai risiko melahirkan anak BBLR sebesar 1,15 kali (95\% CI 0,9-1,4) dibandingkan ibu tidak merokok pasif, setelah dikontrol variabel status ekonomi keluarga dan paritas. ${ }^{10}$

Penelitian Benkaddour et al. pada tahun 2016 di Morocco dengan desain studi kasus kontrol menemukan hasil yang berbeda, dimana ibu yang mempunyai suami perokok (perokok pasif) mempunyai risiko 1,7 kali mengalami BBLR. ${ }^{17}$ Penelitian lainnya di Surakarta dengan desain studi kasus kontrol menemukan bahwa ibu hamil dengan status perokok pasif secara signifikan mempunyai risiko lima kali lebih besar dibandingkan ibu hamil bukan perokok pasif untuk melahirkan bayi BBLR. Setelah mengontrol variabel status ANC, risiko tersebut naik menjadi 5,4 kali lebih besar dan secara statistik signifikan (OR 5.37; 95\% CI 1,5119,12). ${ }^{18}$

Dalam studi yang dilakukan oleh Bardy, sekitar 38 persen ibu dengan kadar cotinine positif merupakan perokok pasif. Studi lain meneliti efek dari paparan asap rokok dari suami terhadap berat lahir pada ibu yang menolak mengkonsumsi tembakau. Dalam penelitian ini, kadar cotinine tali pusat darah diukur pada 175 bayi baru lahir. Bayi baru lahir yang terpapar asap rokok dari ayah yang mengkonsumsi lebih dari 20 batang rokok per hari selama kehamilan ibu akan mengalami defisit berat badan lahir rata-rata sekitar 88 gram. Sebuah penelitian di Denmark menunjukkan bahwa ibu yang tidak merokok dan terpapar terhadap asap rokok di dalam dan di luar rumah melahirkan anak dengan berat badan lahir rata-rata sekitar 79 gram lebih rendah daripada wanita yang tidak terpapar. Ibu perokok pasif mempunyai risiko 1,8 kali melahirkan bayi dengan berat lahir rendah dan terdapat efek linear, dosis tergantung dari log cotinine pada rata-rata berat badan lahir. Studi ini menunjukkan bahwa paparan pasif dapat menyebabkan kadar cotinine yang dapat diukur pada ibu, dan ini dapat mempengaruhi bayi berat lahir rendah. ${ }^{19}$

Terganggunya penyampaian oksigen ke janin merupakan penyebab utama terjadinya berbagai efek buruk akibat merokok pada perempuan hamil. Evaluasi patologik pada plasenta perempuan hamil yang merokok membuktikan adanya perubahan struktural, termasuk penurunan fraksi volume kapiler dan peningkatan kekebalan membran vitelinus jika dibandingkan dengan bukan perokok. Kedua faktor ini mungkin berperan pada pertukaran gas yang abnormal di dalam plasenta. Paparan asap rokok secara akut juga menurunkan perfusi intervilosa, kemungkinan melalui vasospasme akibat nikotin. ${ }^{20}$

Merokok pasif merupakan kombinasi antara asap sidestream yang berasal dari ujung rokok yang dibakar dan asap mainstream yang dihembuskan oleh perokok. Environmental Tobacco Smoke (ETS) termasuk dalam golongan karsinogen bersama dengan asbestos, benzen dan gas radon. ${ }^{16}$ Rokok mengandung nikotin yang merupakan zat kimia beracun. Selain nikotin, di dalam rokok juga terdapat senyawa gula, bahan aditif, saus, pemberi rasa, aroma, dan lain-lain, sehingga terbentuk rasa yang memenuhi selera konsumen (perokok). Nikotin dapat menimbulkan ketagihan baik pada perokok aktif maupun perokok pasif. Paparan karbon monoksida akibat merokok menyebabkan pembentukan karboksihemoglobin, yang memiliki efek multiple pada penyampaian oksigen baik sistemis maupun ke janin. Paparan nikotin 
terhadap janin menghasilkan aktivasi simpatis yang menyebabkan akselerasi denyut jantung janin dan penurunan gerak pernapasan pada janin. Pada bayi manusia yang memiliki kadar nikotin yang signifikan pada saat kelahiran memiliki kemampuan terbatas untuk memaksimalkan denyut jantung selama satu jam pertama kehidupannya. ${ }^{20}$

Pada perempuan, merokok selama kehamilan bukan hanya membahayakan ibu perokok, tetapi juga janin yang dikandungnya. Perempuan hamil yang merokok memiliki risiko yang meningkat terhadap infertilitas, kehamilan etopik, abortus spontan, plasenta previa, abrupsio plasenta, ketuban pecah dini (KPD), persalinan preterm, dan bayi berat lahir rendah. ${ }^{20}$ Tingginya prevalensi laki-laki yang merokok di Indonesia menjadi masalah bagi perempuan dan anak karena dampak negatif dari asap rokok (Environment of Tobacco Smoke/ ETS) terhadap kesehatan mereka. Pada perempuan hamil, keterpaparan terhadap asap rokok dapat mengganggu perkembangan fetus. ${ }^{21}$

Penelitian ini menggunakan desain cross sectional dimana variabel independen dan variabel dependen diukur secara bersamaan sehingga tidak dapat menentukan sebab akibat dari paparan dan penyakit (berpotensi menimbulkan ambiguitas hubungan sebab akibat). Power of study dalam penelitian ini sangat baik yaitu $99 \%$ artinya sampel penelitian cukup besar, namun hasil penelitian ini tidak bermakna. Kemungkinan terdapat pengukuran variabel paparan asap rokok yang kurang tepat atau kurang sensitif. Tidak semua faktor risiko dapat diteliti dan diperhitungkan dalam analisis seperti berat badan sebelum dan selama kehamilan, pengukuran haemoglobin darah, status gizi selama hamil (indeks masa tubuh/IMT), usia pertama kali merokok, kebiasaan merokok di dalam ruangan dengan anggota rumah tangga lainnya, pajanan di tempat kerja, ruang publik, dan transportasi. Variabel paparan asap rokok hanya berdasarkan informasi yang menanyakan status merokok saja. Dampak asap rokok pada BBLR cenderung bersifat paparan kronik, sehingga diperlukan data periode waktu atau berapa lama ibu terpapar asap rokok suami. Menurut Norsa'Adah dan Salinah, kuatnya hubungan antara perokok pasif dengan BBLR ditentukan oleh jumlah perokok, jumlah batang rokok, pola merokok dan jaraknya dengan orang yang tidak merokok. Faktor lingkungan seperti volume ruangan yang terpolusi, ventilasi, dan faktor lain yang mempengaruhi pembuangan asap dan mengubah konsentrasi asap dalam suatu ruangan. ${ }^{22}$

Pengukuran beberapa variabel yakni berat lahir bayi, riwayat merokok ibu, riwayat merokok suami, riwayat kunjungan ANC, dan konsumsi tablet zat besi dilakukan secara retrospektif. Bias tipe ini dapat berakibat pada terjadinya misklasifikasi non-diferensial, dimana informasi yang diperoleh tidak akurat sehingga dapat berpengaruh terhadap akurasi baik outcome maupun pajanan. Terjadinya bias misklasifikasi non-diferensial dalam penelitian ini karena adanya potensi recall bias terkait dengan paparan asap rokok dari suami dan BBLR. Kedua kelompok memiliki kemungkinan yang sama untuk mengalami kesulitan mengingat pajanan dan faktor risiko lainnya yang terjadi di masa lampau. Pertanyaan mengenai hubungan antara merokok pasif dengan bayi berat lahir rendah, pajanan rokok salah satunya didapatkan berdasarkan pengakuan istri dan suami. Pengaruh bias ini dapat memperkecil pengaruh paparan yang sesungguhnya.

Masalah merokok merupakan isu penting pada bidang kesehatan masyarakat, dampaknya bukan hanya pada kesehatan orang yang merokok, tetapi juga kelompok perokok pasif. Dari hasil penelitian ini dan berbagai penelitian lainnya memperoleh hasil bahwa meskipun risiko paparan asap rokok pada ibu perokok pasif dalam mempengaruhi kejadian BBLR tidak sebesar ibu perokok aktif, namun secara jumlah, perokok pasif lebih banyak daripada perokok aktif. Dalam penelitian ini 73 persen suami dari wanita usia 15-57 tahun merupakan perokok aktif, dapat diasumsikan bahwa sebagian besar wanita juga terpapar asap rokok dari suami.

Meskipun faktor yang mempengaruhi BBLR sangat banyak dan kompleks, namun hal ini dapat dicegah sejak dini. Salah satunya adalah dengan melindungi masyarakat dari paparan asap rokok melalui upaya pencegahan dan promosi kesehatan. Pemerintah telah mengeluarkan beberapa kebijakan terkait pengendalian rokok diantaranya UndangUndang 36 tahun 2009 tentang Kesehatan, 
pasal 115 yang mengatur tempat khusus bagi perokok di fasilitas umum, kantor dan menetapkan kawasan tanpa rokok $^{23}$ dan peraturan tentang pengamanan bahan yang mengandung zat adiktif yang berupa produk tembakau bagi kesehatan yaitu dalam Peraturan Pemerintah 109 Tahun 2012 pasal 52. .

\section{KESIMPULAN}

Proporsi ibu usia 15-57 tahun yang terpapar asap rokok dari suami adalah 73,5 persen dan proporsi bayi berat lahir rendah yang dilahirkan oleh ibu dengan suami perokok aktif sebesar 7,5 persen. Proporsi kejadian BBLR pada ibu yang mempunyai suami perokok aktif sedikit lebih tinggi dari pada ibu yang mempunyai suami tidak merokok, meskipun menunjukkan perbedaan yang tidak bermakna (PR 1,096; 95\% CI 0,721-1,66). Dengan beberapa keterbatasan dalam studi ini, dapat disimpulkan bahwa masih diperlukan studi dengan disain studi kohort prospektif untuk mengetahui hubungan antara paparan asap rokok dari suami dengan kejadian BBLR. Selain itu perlu informasi mengenai pajanan dari tempat lain seperti pajanan asap rokok di tempat kerja, ruang publik, serta transportasi umum supaya diperoleh hasil yang lebih baik atau lebih mendekati estimasi hubungan yang sebenarnya.

\section{SARAN}

Masyarakat perlu berpartisipasi aktif dalam menciptakan rumah bebas asap rokok untuk melindungi perokok pasif. Menciptakan rumah bebas asap rokok merupakan hal yang harus segera dilakukan untuk melindungi orang yang dicintai dari paparan asap rokok. Gerakan rumah bebas asap rokok dapat berhasil apabila dilakukan secara serentak oleh semua warga negara dan didukung oleh pihak-pihak terkait seperti pusat kesehatan, dan pemerintah daerah.

Data IFLS sudah cukup baik, perlu memperbaiki kualitas pengumpulan data sehingga meminimalisir terjadinya missing data yang cukup banyak. Kuesioner mengenai riwayat merokok perlu ditambahkan informasi mengenai durasi merokok, frekuensi merokok per hari, serta durasi terpajan asap rokok. Selain itu, pajanan dari tempat lain seperti pajanan asap rokok di tempat kerja, ruang publik, serta transportasi.

\section{UCAPAN TERIMA KASIH}

Peneliti mengucapkan terima kasih kepada pemilik data IFLS yaitu RAND dan Survey Meter, Lembaga Pengelola Dana Pendidikan (LPDP), secara khusus dosen Departemen Epidemiologi dan Fakultas Kesehatan Masyarakat Universitas Indonesia.

\section{DAFTAR PUSTAKA}

1. United Nations Children's Fund World Health Organization, World Bank Group, United Nations Population Division. Levels \& Trends in Child Child Mortality Report 2017 Estimates Developed by the UN Inter-agency Group for Child Mortality Estimation. 2017;40.

2. World Health Organization. Global Nutrition Targets 2025 Low Birth Weight Policy Brief. 2014.

3. Ohlsson a, Shah P. Determinants and prevention of low birth weight: a synopsis of the evidence. Inst Heal Econ Albert Canada. 2008;(December 2008):1-284.

4. World Health Organization. WHO recommendations for the prevention and management of tobacco use and secondhand smoke exposure in pregnancy. 2013;104.

5. IAKMI TCSC. Masalah Rokok di Indonesia. Glob Adult Tob Surv. 2011;

6. Lestari KSD, Putra IWGAE, Karmaya M, Lestari KSD, Putra IWGAE, Karmaya M. Paparan Asap Rokok pada Ibu Hamil di Rumah Tangga terhadap Risiko Peningkatan Kejadian Bayi Berat Lahir Rendah di Kabupaten Gianyar Household Smoke Exposure as Risk Factor of Low Birth Weight among Infants in Gianyar Pendahuluan Metode Penelitian ini meng. 2015;3:13-9.

7. Andriani H, Kuo HW. Adverse effects of parental smoking during pregnancy in urban and rural areas. BMC Pregnancy Childbirth. 2014;14(1):1-15.

8. Drope J, Schluger N, Cahn Z, Drope J, Hamill S, Islami $F$, et al. The Tobacco Atlas. American Cancer Society and Vital Strategies. 2018. 
9. Isroaini A, Saidah N. Hubungan Suami Perokok dengan terjadinya Bayi Berat Badan Lahir Rendah di RSUD Sidoarjo. 2012;4(2):81-101.

10. Rasyidin RUI. Hubungan Antara Merokok Pasif Pada Ibu Usia 15-54 Tahun Dengan Kejadian Berat Badan Lahir Rendah (Analisis Riset Kesehatan Dasar 2013. Tesis. 2015;

11. Kementerian Kesehatan Republik Indonesia. Laporan Nasional Riskesdas 2007. Badan Penelitian dan Pengembangan Kesehatan Departemen Kesehatan, Republik Indonesia Desember 2008. Jakarta; 2008.

12. Badan Penelitian dan Pengembangan Kesehatan. Riset Kesehatan Dasar (RISKESDAS) 2013. Lap Nas 2013. 2013;1-384.

13. Penelitian dan Pengembangan Kesehatan Kementerian Kesehatan RI. Laporan Riskesdas 2018. J Chem Inf Model. 2018;53(9):181-222.

14. Vinet L, Zhedanov A. A "missing" family of classical orthogonal polynomials. J Phys A Math Theor. 2011;44(8):1-100.

15. Badan Pusat Statistik, Badan Koordinasi Keluarga Berencanan Nasional, Departemen Kesehatan, Macro International. Survei Demografi dan Kesehatan Indonesia 2012. Sdki. 2013;16.

16. Goel P, Radotra A, Singh I, Aggarwal A, Dua D. Original Article - Effects of passive smoking on outcome in pregnancy. J Postgrad Med. 2004;50(1):12-6.

17. Benkaddour YA, Fatih B, Majdi F, Soummani A. Passive Smoking and Other Principal Risk Factors Associated with Low Birth Weight. 2016;(June):390-5.

18. Bening Rahimi Titisari. Hubungan Ibu Hamil Sebagai Perokok Pasif Dengan Berat Bayi Baru Lahir. Fakultas Kedokteran Universitas Sebelas Maret; 2011.

19. Reeves S, Bernstein I. Effects of maternal tobacco-smoke exposure on fetal growth and neonatal size. Expert Rev Obstet Gynecol. 2008;3(6):719-30.

20. Sayoga S. Penyakit-Penyakit Pada Kehamilan: Peran Seorang Internis. Laksmi PW, Alwi I, Setiati S, Masjoer A, Ranita R, editors. Jakarta: Pusat Penerbitan Ilmu Penyakit Dalam Fakultas Kedokteran Universitas Indonesia; 2008. 484 p.

21. Julianty Pradono, Kristanti CM. Perokok pasif bencana yang terlupakan. Bul Penel Kesehatan. 2003;31:211-22.

22. Norsa'Adah B, Salinah O. The effect of second-hand smoke exposure during pregnancy on the newborn weight in Malaysia. Malaysian J Med Sci. 2014;21(2):44-53.

23. Kemenkes. Undang-undang Republik Indonesia No. 36 Tahun 2009 Tentang Kesehatan. Undang Republik Indones. 2009;1-48. 